University of Michigan Law School

University of Michigan Law School Scholarship Repository

Law \& Economics Working Papers

$10-5-2017$

\title{
Slicing and Dicing: The Structural Problems of the Tax Reform Framework
}

Reuven S. Avi-Yonah

University of Michigan Law School, aviyonah@umich.edu

Follow this and additional works at: https://repository.law.umich.edu/law_econ_current

Part of the Law and Economics Commons, and the Tax Law Commons

Working Paper Citation

Avi-Yonah, Reuven S., "Slicing and Dicing: The Structural Problems of the Tax Reform Framework" (2017). Law \& Economics Working Papers. 137.

https://repository.law.umich.edu/law_econ_current/137

This Article is brought to you for free and open access by University of Michigan Law School Scholarship Repository. It has been accepted for inclusion in Law \& Economics Working Papers by an authorized administrator of University of Michigan Law School Scholarship Repository. For more information, please contact mlaw.repository@umich.edu. 
SLICING AND DICING:

THE STRUCTURAL PROBLEMS OF THE TAX REFORM FRAMEWORK

Reuven S. Avi-Yonah

The University of Michigan

1. Introduction: The Two Elements of Tax Reform

The "Unified Framework for Fixing Our Broken Tax Code" (the "Framework") released by the "Big Six" group of Treasury, White House and Congressional leaders on September 27 has been the focus of a lot of commentary. Most of the comments have focused on the distributive aspects of the plan and on the proposed rate structure, as well as the impact on revenues and the federal deficit. In this comment, I plan to focus instead on the structural aspects of the plan and in particular on the various new lines that it draws, because these are more likely to be lasting.

Any tax reform has two major elements. The first is the rate structure for individuals and corporations. Rates are important because of their distributive implications and impact on revenues, as well as their incentive effects. But the rate structure of tax reform rarely lasts. Republican administrations since Reagan have tended to cut the tax rates, and Democratic administrations have raised them. The top individual marginal tax rate was cut by Reagan and by George W. Bush and raised by Clinton and Obama. Rates are a major focus of our political debate and so it is understandable that they would be affected by elections and changes in administration.

The second element of tax reform is changes in the structure of the tax system, and those tend to be more lasting. The 1986 tax reform, for example, strengthened the corporate tax and drew a dividing line between publicly traded entities that are taxed as $C$ corporations and whose shareholders pay a second tax on dividends and non-publicly traded entities that are typically taxed on a pass-through basis at the shareholder or partner level. This line has persisted ever since and has led directly to the growth of the pass-through sector (especially after LLCs were invented in the 1990s). The top individual rate and the rate on dividends have changed several times in the past thirty years, but the basic division between $\mathrm{C}$ corporations and pass-throughs remains the same. 
Another example is the equivalence between the rate on dividends and the rate on capital gains, which was set by then House Ways and Means Chair Thomas in 2003 contrary to the wishes of the Bush administration (which had proposed a zero rate on dividends). This equivalence is an important structural feature that significantly reduces the pressure on the distinction between dividends and redemptions which is the focus of several complicated Code sections. The rate on dividends and capital gains was changed twice since then, but the structural equivalence has been maintained.

Thus, it is important to focus on the structural features of the Framework, which draws several important new lines in the tax code. In general, every time a line is drawn in taxation, effort is needed to police it and prevent inappropriate shifting of income across it. This comment will evaluate the new lines drawn in the business and international provisions of the Framework.

2. Line One: Individual vs. Pass-Through

The most important structural innovation of the Framework is the adoption of a new maximum tax rate $(25 \%)$ for the business income of pass-throughs (sole proprietorships, partnerships including LLCs, and S corporations). Under current law, such income is taxed the individual rate of the proprietor, shareholder or partner. Since most pass through are owned by high income individuals, this is a significant tax cut from $39.6 \%$ to $25 \%$. Under the rate structure of the Framework, the differential would still be large (at least $35 \%$ to $25 \%$, although there could also be a higher bracket than $35 \%$ for high income individuals).

We have never treated pass-throughs as separate taxable entities, for good reasons: Entity taxation is problematic because the tax is not borne by the entity (only people can bear tax burdens) and there is uncertainty regarding who bears the burden of the tax (a disputed subject among economists). In the case of $C$ corporations, we have no choice but to tax them because pass-through taxation of publicly traded entities is administratively impossible (we could tax the shareholders based on the value of the shares, but that is politically difficult). But income earned by pass- throughs can be taxed to the owners, and that is clearly the best way to maintain taxation based on individual ability to pay.

Instead, the Framework proposes to tax pass-through business income at a significantly lower rate, while other types of ordinary income of individuals, such as wages, are taxed at a significantly higher rate. This line would clearly create an incentive for high income individuals to transform their wage income (taxed at $35 \%$ or higher) into business income (taxed at $25 \%$ ) by establishing an LLC or S corporation or even a sole proprietorship. Precedents for this problem are troubling, since this is precisely the line that was crossed by hedge fund managers characterizing carried interest as capital gains rather than ordinary income and by numerous professionals using $\mathrm{S}$ corporations to avoid the payroll tax on wages. 
The Framework acknowledges this issue and states that it "contemplates that the committees will adopt measures to prevent the recharacterization of personal income into business income to prevent wealthy individuals from avoiding the top personal tax rate." But it is hard to see how this can be done given that most business income earned through pass through is the result of labor effort by the owners (lawyers, accountants, physicians and other professionals, as well as investment managers and consultants) rather than capital investments or manufacturing (which tends to be done by $\mathrm{C}$ corporations). There is no meaningful distinction between those types of service activities and labor performed for a wage. Thus, it is likely that under the Framework the only people who will pay taxes at $35 \%$ are those unfortunates who are employees of someone else, and who are also subject to withholding and to payroll taxes. Anyone who is self-employed (by themselves or as part of a group) will be able to benefit from the $25 \%$ rate, with no obvious justification (many of these businesses are hardly "small", with revenues of many millions).

3. Line Two: Corporate vs. Pass-Through

A related line drawn by the Framework is between C corporations that will be taxed at $20 \%$, but with lower effective tax rates due to expensing (discussed below), and pass-throughs that will be taxed at $25 \%$. This rate structure is similar to the differential under current law (35\% for C corporations, but with lower effective rates, vs. $39.6 \%$ for pass-throughs) but income earned through $\mathrm{C}$ corporations will continue to be taxed twice (the Framework does not change dividend or capital gain taxation). The result will be a continuation of the current trend for businesses to go private and avoid the $\mathrm{C}$ corporation form. While this line is more defensible because public trading is a meaningful non-tax feature, the disincentive to operate as a $\mathrm{C}$ corporation could have been mitigated by setting the pass through rate at the same level as the corporate rate. That would still leave the double tax issue, and the Framework does contemplate reducing it (perhaps by granting a dividend paid deduction as proposed by Sen. Hatch).

4. Line Three: Expensing

Another important innovation in the Framework is expensing (immediate deduction) for new investments in depreciable assets other than structures made after September 27, 2017 for at least five years, with potential extension. The Framework seems to extend this to all businesses, but as a practical matter the main effect will be on $\mathrm{C}$ corporations since they make most tangible business investments in depreciable property.

It is well established that expensing is equivalent to exempting the normal return from the expensed investment from tax. Thus, in principle this is a very important innovation because it can translate into a zero corporate tax rate. However, I am doubtful that the immediate effect will be significant because the normal return under current interest rate conditions is very low (as opposed to the last time effective expensing was tried in 1981, when interest rates were very high). Nevertheless, expensing sets an important structural precedent that will be hard to 
take away after five years (a limit that presumably was set by revenue considerations). Under a different interest rate environment expensing could become very important and even make the US into a giant corporate tax haven from the perspective of the rest of the world (see below).

The important line here is between businesses that would benefit from expensing because they make a lot of tangible investments, mainly old style manufacturing operations, and businesses that do not because they already deduct R\&D and human capital. The latter are all the cutting edge businesses in the economy (Google, Amazon, Apple etc.) and expensing is unlikely to eliminate their advantage in drawing the best and the brightest. I would think that business support for this proposal is likely to be lukewarm, especially since it is just a timing issue and does not help increase earnings per share.

5. Line Four: Interest Deductibility

Expensing requires a limitation on interest deductibility because if it is possible to deduct interest and use the borrowed funds to invest in functionally exempt returns (under expensing as well as exempt dividends from offshore subsidiaries) the result is negative tax rates. The Framework envisages a "partial" limit on interest deductibility by C corporations and will "consider the appropriate treatment of interest paid by non-corporate taxpayers." If expensing is allowed for pass-throughs, it will be necessary to limit interest deductibility for those businesses as well.

There are two problems with this line. The first is the continuing differential treatment of debt and equity, since interest will be partially deductible while dividends presumably will not be, and interest will be taxable in full to the recipient while dividends qualify for a reduced rate. This is a notoriously difficult line to police especially with modern financial instruments.

The second problem is that financial institutions will have to be excluded because they cannot function without the interest deduction (a bank earns interest and if it cannot deduct interest it will be grossly over-taxed). But it is notoriously hard to draw a line between financial institutions and other C corporations, especially in this age of "shadow banks" and FinTech.

6. Line Five: Domestic vs. Foreign

The Framework adopts "territoriality." i.e., exempting in full dividends from foreign subsidiaries in which the US parent owns at least a $10 \%$ stake. It adopts a one-time tax on past offshore earnings, with a lower rate for illiquid assets than for cash equivalents, and with the liability spread out over several years (presumably to mitigate the hit to the financial statements since these $\$ 2.5$ trillion are largely deemed permanently invested offshore and no reserve has been taken for tax). While this treatment of past earnings is likely to result in large repatriation of funds, the experience of the 2004 amnesty has shown that this does not translate into more jobs but instead benefits wealthy shareholders through share repurchases. 
The obvious line here is between domestic profits (taxed at 20\%, but potentially with a lower effective rate due to expensing) and foreign profits (taxed at zero). This creates an obvious incentive to shift profits from the US to foreign jurisdictions, especially where the foreign tax rate is also zero (i.e., tax havens). This incentive obviously also exists under current law, but it is mitigated by the current tax on dividends (since the multinational cannot currently repatriate without paying tax at 35\%). Adopting a dividend exemption even with a lower corporate rate would significantly increase the incentive to shift profits overseas (the new lower corporate rate even with expensing is not very different from the current effective rates of most US MNEs that already write off R\&D and human capital costs).

The Framework addresses this problem by imposing a current minimum tax on the foreign profits of US multinationals. But it does not specify the rate, and while any minimum tax would be an improvement over the current situation in which most offshore income is taxed at very low rates, presumably the intent would be to set the minimum rate at significantly below the $20 \%$ domestic rate. Any such differential would preserve the enhanced incentive to shift profits offshore in the knowledge that they can be repatriated tax free.

In addition, the minimum tax preserves the existing line between US based multinationals (subject to the minimum tax) and foreign-based multinationals (not so subject, if the right jurisdiction is chosen). The result will be continuing inversions. The Framework promises to "level the playing field between US-headquartered parent companies and foreignheadquartered parent companies," but it is unclear how this can be achieved as long as US resident corporations pay any tax based on residence.

From the perspective of foreign multinationals in some jurisdictions, it is possible that the lower US corporate tax rate plus expensing will increase inbound investment (i.e., the US will become a giant corporate tax haven). However, if the resulting effective tax rate is too low, this will trigger foreign CFC rules that typically hinge on the effective tax rate in the target jurisdiction.

7. Conclusion: Can Fewer Lines be Drawn?

If we adopt the framework, these structural features of tax reform will be hard to change. Specifically, we are unlikely to give up on a lower rate for pass-throughs, expensing, and territoriality. These will be popular provisions that even future Democratic administrations will find hard to touch (as shown by the disastrous experience with "check the box", which is still with us despite repeated commitments to abolish it).

In my opinion, we could do with fewer lines, and those should be defensible. I would drop the pass-through proposal since I do not believe the line between pass-through businesses income and wages can be defended. I would maintain the current distinction between $\mathrm{C}$ corporations and pass- throughs, since that line (public trading) is more easily defended because it relates to 
non-tax attributes, and because I do not believe in unnecessary entity taxation. I would also drop the expensing proposal since it creates unjustified winners and losers and because it requires limits to interest expense that I do not believe can be defended (the debt/equity and bank/non-bank lines). Finally, I would drop territoriality since I do not think the domestic/foreign line can be defended.

Instead, I would keep much of the current structure: A top rate for individuals that also applies to pass-through income; and a lower rate for $\mathrm{C}$ corporations, since that is needed for competitiveness purposes, with a second tax on dividends and capital gains. I would support two major changes. The first would be to set the dividends and capital gains rate at the top ordinary income rate, as we did (for capital gains) in 1986, even if the result is a lower rate on ordinary income. A lower rate for capital gains is required to mitigate lock-in (I would support a mark to market regime, but believe it is not politically feasible), and the gain from taxing the rich more on dividends and capital gains offsets the lower corporate tax and lower tax on wages.

The second change would be to extend the new corporate tax rate to foreign income, past as well as future. There is no competitiveness reason not to tax past accumulated earnings in full. For future earnings, the only way to prevent profit shifting and allow tax free repatriations is to apply the same rate to all corporate income. The rate should be set at whatever level is needed to maintain future competitiveness, and the existence of robust CFC rules in most of the world means that the effective rates of our major competitors are not so low that this would require a rate much below $20 \%$. Such a rate would still lead to incentives to invert to countries with no CFC rules, but that line can be defended by redefining corporate residence by location of headquarters and imposing a corporate exit tax. That is what our major competitors do, and there are no inversions from European countries or Japan. 